\title{
Corrosion Analysis of Friction Stir-welded AA 7075 Aluminium Alloy
}

\author{
Govindaraj Elatharasan - Velukkudi Santhanam Senthil Kumar* \\ Anna University, College of Engineering, Guindy, India
}

Friction stir-welding of AA7075 has become widely practiced in the fabrication of light-weight structures requiring high strength-to-weight ratios and superior corrosion resistance. The friction stir-welding (FSW) process and tool parameters play a key role in determining the joint's characteristics. In this paper, the corrosion resistance of a friction stir-welded alloy was studied via polarization and electrochemical impedance spectroscopy in $3.5 \% \mathrm{NaCl}$. The microstructure of different positions along the thickness of the aluminium alloy plate has been investigated with regard to varying parameters, including rotary speed and transverse speed. The heat-affected zones of the weld exhibited the highest susceptibility to inter-granular corrosion. The results also show that sound joints in AA7075 can be achieved using friction stirwelding. Corrosion resistance decreases with the increase of traverse speed from 0.37 to $0.76 \mathrm{~mm} / \mathrm{s}$ at a rotary speed of $800 \mathrm{rpm}$. Corrosion resistance at a rotary speed of $1000 \mathrm{rpm}$ is lower than that at $1200 \mathrm{rpm}$; an increase in the corrosion resistance may also be reached via the breaking down and dissolution of the inter-metallic particles.

Keywords: friction stir-welding, aluminium alloy, AA7075, corrosion

\section{INTRODUCTION}

Friction stir-welding (FSW), a new solid-state joining technique, was invented by The Welding Institute (TWI) [1]. This technique avoids the formation of solidification cracking and porosity. Moreover, it significantly improves the weld properties and has been extensively applied in joining light metals [2], especially aluminium and its alloys. FSW is ideal for joining aluminium alloys; especially the AA2000 and AA7000 series [3]. High-strength aluminium alloys, such as $7 \mathrm{XXX}$, are commonly used in aerospace applications due to their light weight and high strength. These alloys are difficult to weld using conventional fusion welding and are typically joined though FSW [4]. Friction stir-welding has been successfully used in joining primary structures in the Eclipse $500^{\mathrm{TM}}$ jet [5].

The corrosion properties of FSW in 2XXX, 5XXX and 7XXX series aluminium alloys have been studied by a number of authors [6,7]. For highstrength alloys, such as 7075 , the heat-affected zones of the weld exhibit the highest susceptibility to intergranular corrosion, which correlates with copper depletion along the grain boundaries [8]. An analysis was conducted on the welded surfaces instead of the section [9], taking into account that the surface is the part more exposed to the environment. Corrosion being a surface phenomenon, an approach of reducing or removing these second phase particles from the surface can be adopted. In such a situation, the corrosion resistance of the alloy is expected to be improved. The composition of the micro-constituents (i.e. their size, quantity, location, continuity and corrosion potential relative to that of the adjacent $\alpha$-Al matrix) is the decisive aspect of microstructure that affects the corrosion behaviour of the alloy [10]. Recent work on AA2024 T351 [11] showed the correlation between welding parameters (rotation speed and travel speed) on the corrosion behaviour and the precipitation of the age-S phase, while for the $7 \mathrm{XXX}$ alloys, changes in electrochemical behaviour have been attributed to the precipitation of the $\eta$ phase.

The corrosion behaviour of FSW aluminium alloys has been studied in recent years [12]. Generally, it has been found that the weld zones are more susceptible to corrosion than the parent metal. Buchheit [13] and Paglia [14] evaluated stress corrosion cracking susceptibility of friction stirwelded 7050-T7451 and 7075-T651, using the SSRT method in a $\mathrm{NaCl}$ solution. Peening techniques, such as shot and laser peening, can be helpful in mitigating the surface residual stresses, and therefore enhance the fatigue properties and SCC.

Trdan et al. [15] confirmed that the specimens of $\mathrm{AlMgSiPb}$ alloy after corrosion testing were shown to be a more corrosion resistant material with a smaller number of pits than $\mathrm{AlSi}_{1} \mathrm{MgMn}$ aluminium alloy.

Oosterkamp et al. [16] identified that the role of the tool pin in friction stir-welding is to shear the material to its back side during the translation of the tool, and the inserted rotating pin brings the material at both sides of the joint line to the plastic state, aided by the frictional heat input of the shoulder.

Elangovan et al. [17] identified that the triangular pin profiled tool showed almost matching tensile properties to that of square pin followed by threaded, taper and straight cylindrical pins, respectively. 
In this study, the corrosion properties of the friction stir-welded 7075-T6 aluminium alloy plates have been investigated by polarization and electrochemical impedance spectroscopy in 3.5\% $\mathrm{NaCl}$. The root side of the weld exhibited the highest susceptibility to inter-granular corrosion.

\section{EXPERIMENTAL PROCEDURE}

Aluminium alloy AA7075-T6 (Al-Zn-Mg-Cu), for which $\mathrm{T} 6$ heat treatment consists of being solution heat treated and artificially aged at $190^{\circ} \mathrm{C}$ for $12 \mathrm{~h}$, and H321 denotes a strain hardened and stabilized condition, with the alloy approximating the quarterhard state after the thermal stabilization treatment. AA7075-T6 is one of the strongest aluminium alloys currently in industrial use.

Table 1. Chemical composition [wt. \%] of base metal

\begin{tabular}{ccccccccc}
\hline & $\mathrm{Mg}$ & $\mathrm{Mn}$ & $\mathrm{Zn}$ & $\mathrm{Fe}$ & $\mathrm{Cu}$ & $\mathrm{Si}$ & $\mathrm{Cu}$ & $\mathrm{Al}$ \\
\hline $\mathrm{AA7075}$ & 2.1 & 0.12 & 5.1 & 0.35 & 1.2 & 0.5 & 1.2 & bal \\
\hline
\end{tabular}

Table 2. The mechanical properties of base metal

\begin{tabular}{ccccc}
\hline & $\begin{array}{c}\text { Young } \\
\text { modulus } \\
{[\mathrm{GPa}]}\end{array}$ & $\begin{array}{c}\text { Yield } \\
\text { strength } \\
{[\mathrm{MPa}]}\end{array}$ & $\begin{array}{c}\text { Tensile } \\
\text { strength } \\
{[\mathrm{MPa}]}\end{array}$ & $\begin{array}{c}\text { Elongation } \\
{[\%]}\end{array}$ \\
\hline AA7075 & 71 & 469 & 578 & 11 \\
\hline
\end{tabular}

The alloy derives its strength from precipitation of $\mathrm{Mg}_{2} \mathrm{Zn}$ and $\mathrm{Al}_{2} \mathrm{CuMg}$ phases. The chemical composition of the AA7075- T6 alloy [16] (by weight percentage) given in Table 1. The yield and tensile strengths are given in Table 2.

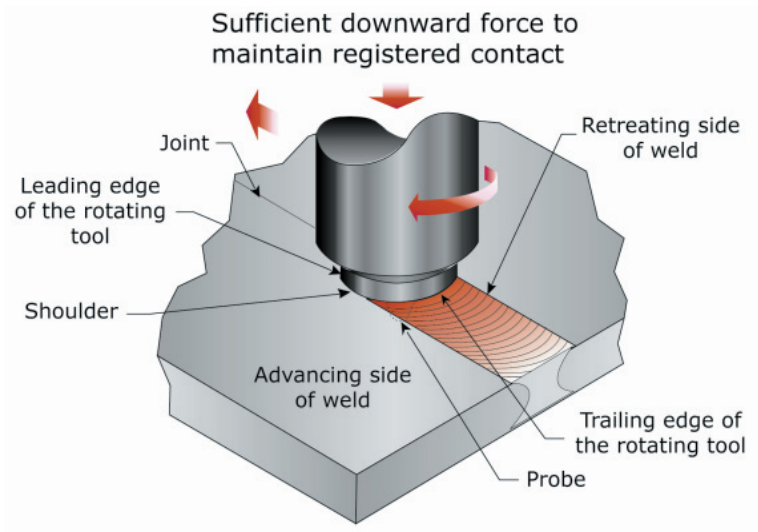

Fig.1. Friction stir-welding operation

Plates having the dimensions of $50 \times 100 \times 6 \mathrm{~mm}$ (width $\times$ length $\times$ thickness) were friction stir-welded. The samples were friction stirred with an indigenously developed machine. The process is shown in Fig.1; it uses a non-consumable threaded tool made of heattreated high carbon steel with a shoulder diameter of $18 \mathrm{~mm}$ by $6 \mathrm{~mm}$ pin diameter and length $5.7 \mathrm{~mm}$. The hardness value was $60 \mathrm{HRC}$, and the tool nomenclature is shown in Fig. 2. Rotational speeds and traverse speeds are varied in this study. Three rotational speeds $(800,1000$ and $1200 \mathrm{rpm})$ and two traverse feeds $(0.37$ and $0.76 \mathrm{~mm} / \mathrm{s})$ were used.

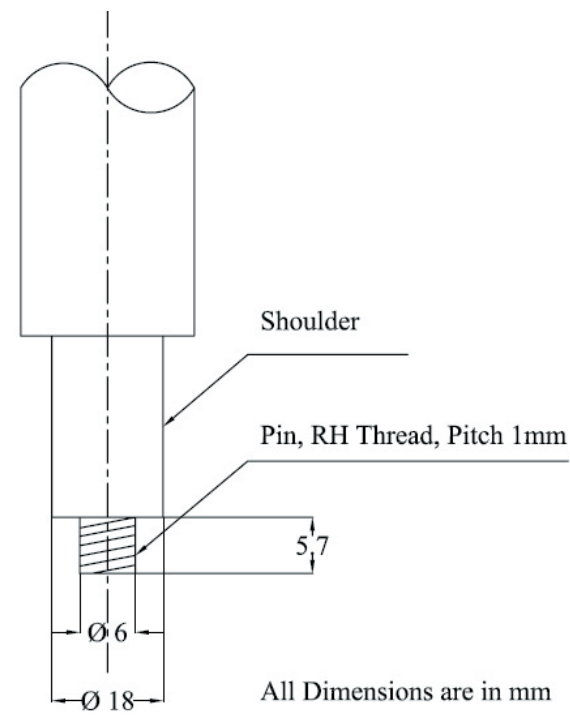

Fig. 2. Friction stir-welding tool nomenclature

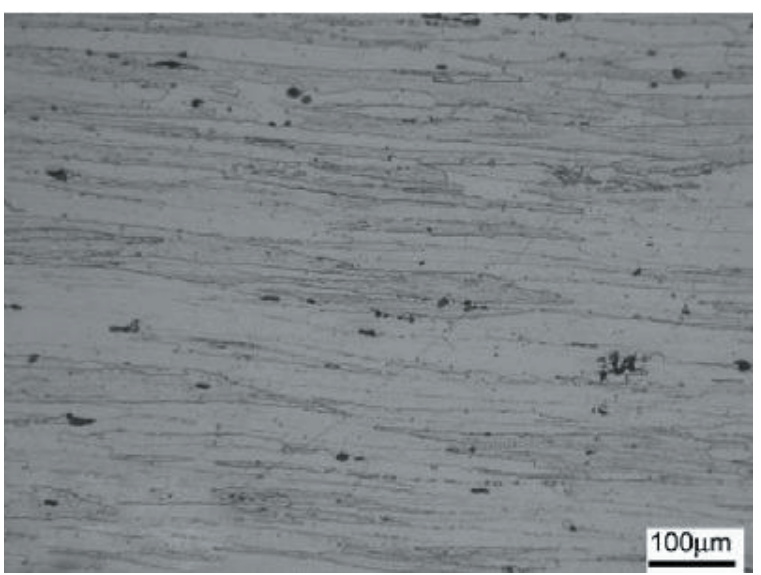

Fig. 3. Microstructure of the parent metal

Fig. 3 shows the microstructure of the AA7075-T6 alloy, revealing the presence of an insoluble (Fe, $\mathrm{Mn}) \mathrm{Al}_{6}$ alloy formed along the direction of rolling. Among the elongated grains of aluminium solid solution, some fine precipitates of $\mathrm{Mg}_{2} \mathrm{Si}$ were also seen. Fig. 4 shows a photo-micrograph of the interface junction of the AA7075-T6 alloy on one side and the weld FSW zone. On the other side, the direction of the 
grain changed due to the spinning action of the tool in AA7075-T6 alloy. The left side shows the weld metal that has fragmented particles of $\mathrm{Mg}_{2} \mathrm{Si}$.

FSW samples of $1 \times 1 \mathrm{~cm}$ were cut from the plate after making slices $1 \mathrm{~cm}$ thick. A 3.5\% sodium chloride solution was used in this study. Electrochemical measurements were made using the Solartron electrochemical system (Model 1280 B).

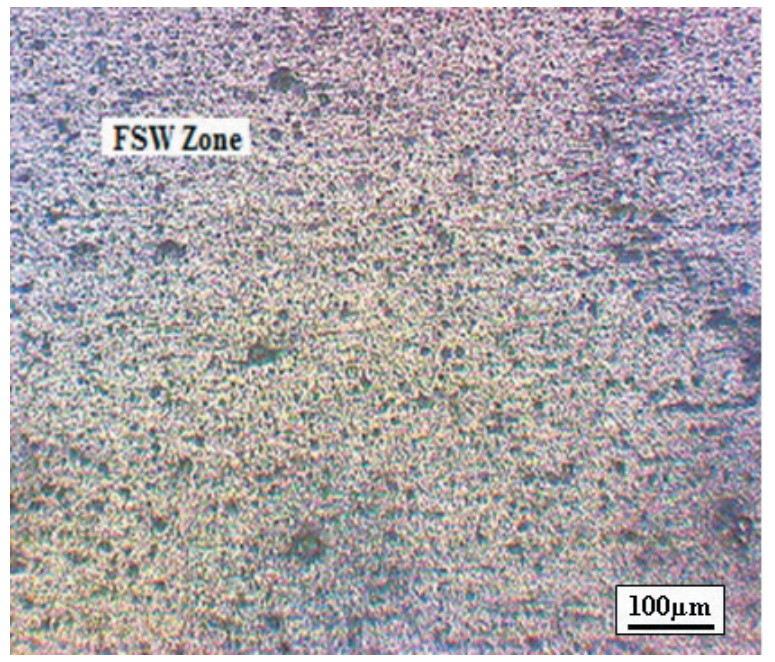

Fig. 4. Microstructure of the stir zone

The 1280B electrochemical workstation provides the combined facilities of an electrochemical interface (ECI) and a frequency response analyser (FRA). The ECI can be used either as a potentiostat or galvanostat with selectable control loop bandwidth to ensure stable operation for various types of cells. The FRA provides a precision signal generator and an analyser for measuring cell impedance data. When used with Z Plot for Windows, it offers a complete range of EIS (Electrochemical Impedance Spectroscopy) techniques, including $\mathrm{AC}$ impedance and harmonic analysis. The use of CorrWare with the 1280B allows all standard DC electro analytical analysis techniques to be programmed, including electrochemical noise. A7075 alloy was used as the working electrode in the conventional three-electrode assembly with platinum foil as counter electrode and saturated calomel electrode (SCE) as reference electrode. For the electrochemical impedance tests, the samples were immersed in the electrolyte for 30 minutes before the test. The samples were exposed in such a way that only the nugget was subjected to the corrosion tests and the rest of the areas were masked. EIS measurements were carried out in the frequency range of $10 \mathrm{kHz}$ to $0.01 \mathrm{~Hz}$.
The aluminium alloy was mechanically polished with $1 / 0,2 / 0,3 / 0$ emery papers and then dipped in a $5 \% \mathrm{NaOH}$ solution for 2 minutes to activate the surface. After this stage, the samples were cleaned with cleaning powder to remove the black smudge formed over the surface, washed thoroughly with running water and then dipped in a concentrated $\mathrm{HNO}_{3}$ solution for 30 seconds.

\section{CHARACTERIZATION STUDIES AND RESULTS}

\subsection{Tafel Polarization}

Fig. 5 shows the typical polarization curves of the samples to find the pitting corrosion resistance. Anodic polarization curves were obtained by exposing the nugget area alone to $3.5 \% \mathrm{NaCl}$ solution at different welding parameters. The material of the stir zone shows a classic passive region with current density, which is practically independent of applied potential up to pitting potential $E_{\text {pit }}$ forming the passive film, which protected the $\mathrm{Al}$ alloy from corrosion. AA 7075 surface studies were carried out by passing a fixed current for a fixed duration of time. In this regard, current densities of 15 and $20 \mathrm{~mA} / \mathrm{cm}^{2}$ were applied, and the corresponding potential transients were recorded for a period of 1 hour.

\subsection{Electrochemical Impedance Measurements}

Electrochemical Impedance Spectroscopy (EIS) a.c. signals of $20 \mathrm{mV}$ amplitude and various frequencies varying from $10 \mathrm{kHz}$ to $0.01 \mathrm{~Hz}$ at open circuit potentials were imposed on the aluminium alloy; the nugget was exposed to a $3.5 \% \mathrm{NaCl}$ solution, and the results were plotted in Fig. 5. From the impedance plots, the charge transfer resistance $\left(R_{c t}\right)$ and the double layer capacitance $\left(C_{d l}\right)$ values were calculated using ZsimpWin 3.21 software with an equivalent circuit, where $R_{S}$ is the solution resistance. In most cases, $k$ is found to be in an order of 0.012 to $0.03 \mathrm{~V}$. The charge transfer resistance $R_{c t}$ is a measure of the corrosion rate and is calculated as [18]:

$$
i_{c o r}=\left(b_{a} * b_{c}\right) /\left[2.3\left(b_{a}+b_{c}\right) R_{c t}\right]=k / R_{c t},
$$

where $i_{c o r}$ is a corrosion current, $b_{a}$ an anodic Tafel slope, and $b_{c}$ a cathodic Tafel slope.

Using the above relationships, the corrosion reactions are determined via Tafel polarisation methods. 
Table 3. Corrosion values on AA 7075 alloy

\begin{tabular}{|c|c|c|c|c|c|c|}
\hline & \multicolumn{2}{|c|}{ Impedance method } & \multicolumn{4}{|c|}{ Polarization method } \\
\hline & $\begin{array}{c}\text { Charge transfer } \\
\text { resistance }\end{array}$ & $\begin{array}{l}\text { Double layer } \\
\text { capacitance }\end{array}$ & $\begin{array}{l}\text { Anodic Tafel } \\
\text { slope }\end{array}$ & $\begin{array}{l}\text { Cathodic Tafel } \\
\text { slope }\end{array}$ & $\begin{array}{c}\text { Corrosion } \\
\text { current }\end{array}$ & $\begin{array}{c}\text { Corrosion } \\
\text { potential }\end{array}$ \\
\hline & $R_{c t}\left[\Omega \mathrm{cm}^{2}\right]$ & $C_{d l}\left[\mu \mathrm{F} / \mathrm{cm}^{2}\right]$ & $b_{\mathrm{a}}[\mathrm{mV}]$ & $b_{c}[\mathrm{mV}]$ & $i_{\text {cor }}\left[\mu \mathrm{A} / \mathrm{cm}^{2}\right]$ & $E_{\text {cor }}[\mathrm{V}]$ \\
\hline $\mathrm{BM}$ & 2915 & 21 & 10.241 & -523.10 & 32 & -0.80786 \\
\hline RSFSW & 7426 & 25 & 10.040 & -823.91 & 42 & -0.87038 \\
\hline CSFSW & 4444 & 14 & 19.250 & -883.78 & 12 & -0.84334 \\
\hline
\end{tabular}

$\mathrm{BM}=$ Base Metal, RSFSW $=$ Root side FSW

\section{DISCUSSION}

\subsection{Corrosion Behaviour}

\subsubsection{Tafel Polarization Test}

Tafel polarization tests were carried out to determine the pitting corrosion resistance. Anodic polarization curves were obtained by exposing only the nugget area to a $3.5 \% \mathrm{NaCl}$ solution. $i_{\text {cor }}$ is the corrosion current density derived by extrapolating the anodic and cathodic Tafel lines at $E_{c o r}$ in the absence of inhibitor. It is found that the corrosion potential $E_{c o r}$ and $\mathrm{i}_{\text {cor }}$ values (as shown in Table 3 on the different welding position) were shifted to a more anodic direction from the bottom $\left(E_{\text {cor }}=0.84334 \mathrm{~V}, i_{\text {cor }}=12 \mu \mathrm{A} / \mathrm{cm}^{2}\right)$ to the top $\left(E_{\text {cor }}=0.87038 \mathrm{~V}, i_{\text {cor }}=42 \mu \mathrm{A} / \mathrm{cm}^{2}\right)$ of WNZ (Weld Nugget Zone), and $t$ along the thickness of $\mathrm{WNZ}$ in a $3.5 \mathrm{wt} . \% \mathrm{NaCl}$ solution at different welding parameters. The polarization resistance decreases from the top to the bottom.

\subsubsection{Electrochemical Impedance Spectroscopy}

Electrochemical Impedance Spectroscopy (EIS) results of the FSW on AA 7075-T6 with $1200 \mathrm{rpm}$ with $3.7 \mathrm{~mm} / \mathrm{s}$ alloy in $3.5 \% \mathrm{NaCl}$. In the case of Tafel polarization, the scanning of potential was done from $-0.2 \mathrm{~V}$ vs. OCP to $+0.2 \mathrm{~V}$ vs. $\mathrm{OCP}$ at a scan rate of $1 \mathrm{mV} / \mathrm{s}$. From this anodic and cathodic polarization curves, the Tafel regions were identified and extrapolated to $E_{c o r}$ to obtain the corrosion potential $i_{c o r}$, using the Corr View software. In the case of electrochemical impedance spectroscopy, a.c. signals of $20 \mathrm{mV}$ amplitude and various frequencies from $10 \mathrm{kHz}$ to $0.01 \mathrm{~Hz}$ at open circuit potentials were impressed to the aluminium alloys. The impedance plots are shown in Fig. 5. It shows the effect of air ageing in the Nyquist representation of complex impedance. The charge transfer resistance $\left(R_{c t}\right)$ and double layer capacitance $\left(C_{d l}\right)$ obtained from these curves is CSFSW $=$ Crown side FSW. given in Table
3, which clearly shows a slight improvement in the corrosion resistance. The low frequency impedance indicates the corrosion resistance of the surface. In Fig. 7, it is observed that the top has higher impedance than that of the bottom, because the semicircle radius of Nyquist plot is as follows: Top $>$ Middle $>$ Bottom.

As expected, the lower traverse speed samples present higher impedance than that exhibited by the higher traverse speed in the same solution.

Fig. 6 shows polarization resistance and a corrosion current density curve for different positions of pitting resistance has improved in all parameters compared to the base material $\left(E_{c o r}=0.80786 \mathrm{~V}\right.$ and $\left.i_{\text {cor }}=32 \mu \mathrm{A} / \mathrm{cm}^{2}\right)$.
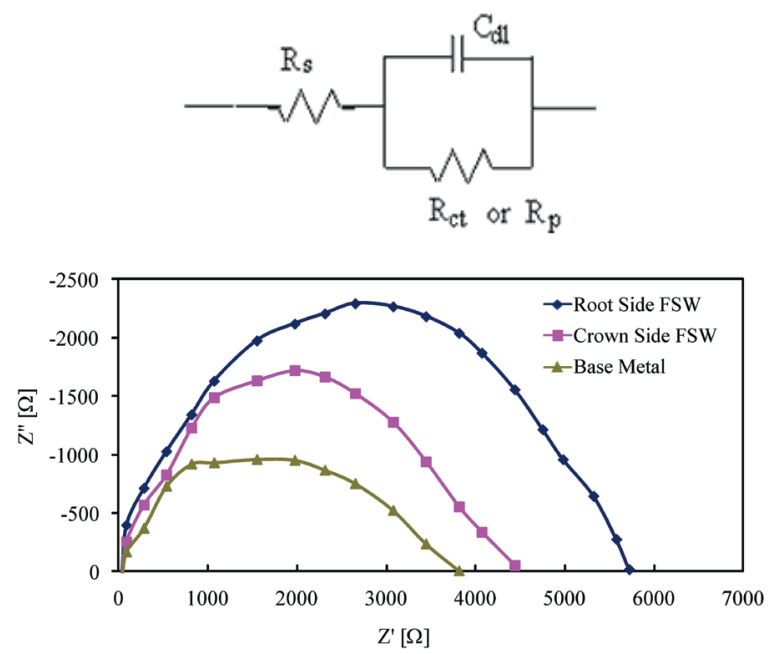

Fig. 5. Impedance behaviour of friction stir-welded AA 7075 alloy at $20 \mathrm{~mA}$ for $1 \mathrm{~h}$ in $3.5 \% \mathrm{NaCl}$

It can also be easily seen that the susceptibility of material corrosion resistance decreases with an increase of traverse speed from 0.37 to $0.76 \mathrm{~mm} / \mathrm{s}$ at rotary speed of $800 \mathrm{rpm}$. Corrosion resistance at rotary speed $1000 \mathrm{rpm}$ is lower than that at $1200 \mathrm{rpm}$. However, the corrosion resistance decreases with increasing rotary speed due to bigger second-phase particles of $\mathrm{Al}-\mathrm{Cu}-\mathrm{Fe}-\mathrm{Zn}$ in the weld. 


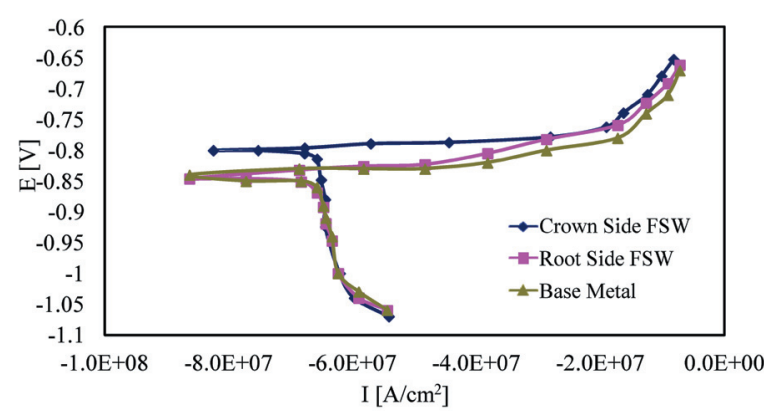

Fig. 6. Effect of the polarization curves for $A A 7075$ at $20 \mathrm{~mA}$ for $1 \mathrm{~h}$ in $3.5 \% \mathrm{NaCl}$

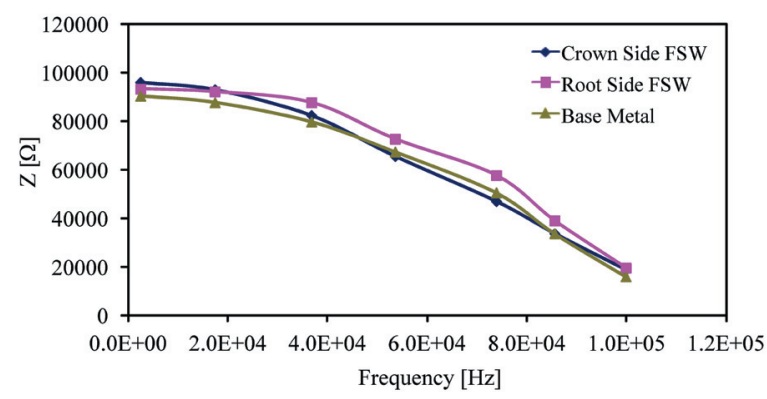

Fig. 7. EIS curves of friction stir-welded AA 7075 alloy for $1 \mathrm{~h}$ in $3.5 \% \mathrm{NaCl}$

\subsection{Microstructural Studies}

The micro-structural analysis of the friction stirwelded samples after corrosion was carried out with a scanning electron microscope (SEM) as shown in Fig. 8.

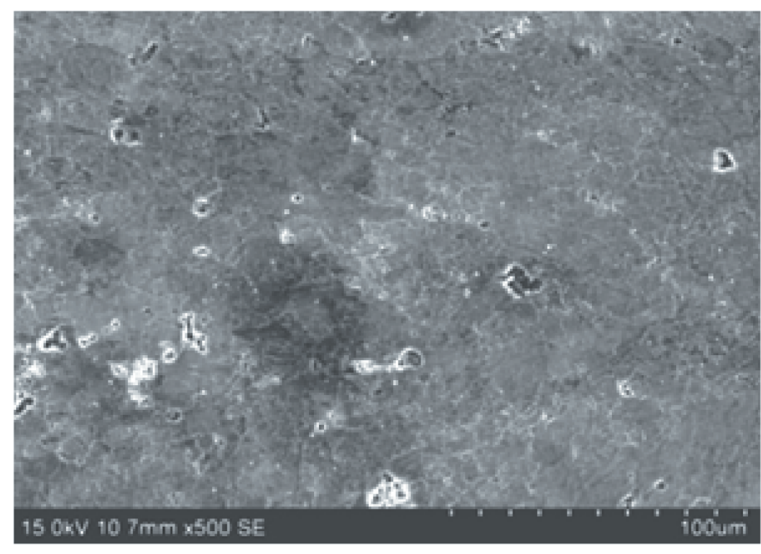

Fig. 8. Scanning Electron Micrograph of FSW AA7075 after Corrosion

The samples were etched using Keller's reagent to reveal the grain boundaries. FSW AA7075-T6 samples were air-dried and observed within a few minutes after being removed from the test solution.
Observation of welded areas of FSW AA 7075-T6 samples showed an initial stage of inter-granular corrosion on a heat-affected zone with the attack of the precipitate-free zones. Note that the presence of small white grain boundary precipitates and the attack of the precipitates-free zone (black). Pitting corrosion usually occurs in the $\mathrm{Al}$ matrix near $\mathrm{Cu}$ or $\mathrm{Fe}$ inter metallic particle. This acts in a cathodic manner to the AA7075 alloy matrix or at Al-Mg-Zn particles, which acts anodic in $3.5 \% \mathrm{NaCl}$ solution.

\section{CONCLUSION}

This investigation shows improvement in the corrosion resistance of FSW in AA7075-T6 exposed to a $3.5 \% \mathrm{NaCl}$ solution at room temperature. The findings of this study can be summarized as follows:

1. FSW AA 7075-T6 alloy surface morphological evaluation in the $3.5 \% \mathrm{NaCl}$ by electrochemical impedance spectroscopy and potentiodynamic polarization exhibited exceptionally high corrosion protection performance.

2. The microstructure presents dynamically recrystallized and fine-equiaxed grain structure. The sizes of second-phase particles $\mathrm{Al}-\mathrm{Cu}-\mathrm{Fe}-$ $\mathrm{Zn}$ increase from the top to the bottom. The Al$\mathrm{Cu}-\mathrm{Fe}-\mathrm{Zn}$ size increases with the increase in the traverse speed.

3. The localized pitting attack is generally associated with second phase particles. Pits may either initiate near an $\mathrm{Al}-\mathrm{Cu}-\mathrm{Fe}-\mathrm{Zn}$ particles, which act catholically to the 7075 alloy matrix, or at $\mathrm{Al}-\mathrm{Mg}-\mathrm{Zn}$ particles, which act anodically to the matrix, thereby preferentially corroding in the $3.5 \% \mathrm{NaCl}$ solution. The fatigue resistance of the corroded specimens drastically decreased in comparison with the parent metal due to material pitting corrosion.

4. The electrochemical test results indicate that the top of weld has the highest icor and Ecor, which are helpful in inhibiting corrosion attack, but the base material has smallest icor and Ecor in all specimens. The maximum polarization resistance and minimum corrosion current density were on top of the weld. According to the EIS measurements and the simulated results by the equivalent circuits, the impedance values are in a sequence of: Top $>$ Middle $>$ Bottom. The improvement in corrosion resistance correlates well with the increase in grain-boundary precipitate size. 


\section{REFERENCES}

[1] Thomas, W.M., Nicholas, E.D. (1997). Friction stir welding for the transportation industries. Materials and Design, vol. 18, no. 4-6, p. 269-273, DOI:10.1016/ S0261-3069(97)00062-9.

[2] Matrukanitz, R.P. (1990). Selection and weldability of heat-treatable aluminium alloys. ASM HandbookWelding, Brazing and Soldering, vol. 6, p. 528-536.

[3] Balasubramanian,V.,Lakshminarayanan, A.K. (2008). The mechanical properties of the GMAW, GTAW and FSW joints of the RDE-40 aluminium alloy. International Journal of Microstructure and Materials Properties, vol. 3, no. 6, p. 837-853, DOI:10.1504/ IJMMP.2008.022618.

[4] Thomas, W.M., Nicholas, D., Needham, J.C., Murch, M.G., Templesmith, P., Dawes, C.J. (1991). Friction-stir butt welding, GB Patent No. 9125978.8, International patent application, South Wales.

[5] Eclipse Aviation, section on Innovation in Eclipse500 aircraft from http://www.eclipseaviation.com/about/ innovations, accessed at: 2012-03-12.

[6] Paglia, C.S., Buchheit, R.G. (2008). A look in the corrosion of aluminium alloy friction stir welds. Scripta Materialia, vol. 58, no. 5, p. 383-387, DOI:10.1016/j. scriptamat.2007.10.043.

[7] Hannour, F., Davenport, A., Strangwood, M. (2000). Corrosion of friction stir welds in high strength aluminium alloys. 2nd International Symposium on Friction Stir Welding, Gothenburg.

[8] Lumsden, J.B, Mahoney, M.W, Pollock, G., Rhodes, C.G. (1999). Intergranular corrosion following friction stir welding of aluminum alloy 7075-T651. Corrosion Science, vol. 55, no. 12, p. 1127-1135, DOI:10.5006/1.3283950.

[9] Zucchi, F., Trabanelli, G., Grassi, V. (2001). Pitting and stress corrosion cracking resistance of friction stir welded AA5083. Materials and Corrosion, vol 52, p. 853-859, DOI:10.1002/1521-4176(200111)52:11<853::AIDMACO853>3.0.CO;2-1.

[10] Dix, E.H.Jr. (1946). Corrosion of light metals (aluminum and magnesium). Corrosion of Metals. American Society for Metals. Cleveland.
[11] Jariyaboon, M., Davenport, A.J., Ambat, R., Connolly, B.J., Williams, S.W., Price, D.A. (2007). The Effect of Welding Parameters on the Corrosion Behaviour of Friction Stir Welded AA2024-T351. CorrosionScience, vol. 49, no. 2, p. 877-909 DOI:10.1016/j. corsci.2006.05.038.

[12] Wadeson, D.A., Zhou, X., Thompson, G.E., Skeldon, P., Djapic Oosterkamp, L., Scamans, G. (2006). Corrosion behaviour of friction stir welded AA7108 T79 aluminium alloy. Corrosion Science, vol. 48, no. 4 , p. 887-897, DOI:10.1016/j.corsci.2005.02.020.

[13] Buchheit, R.G., Paglia, C.S. (2004). Localized corrosion and stress corrosion cracking of friction stir welded 7075 and 7050. Corrosion and Protection of Light Metal Alloys. The Electrochemical Society, New Jersey.

[14] Paglia, C.S., Buchheit, R.G., (2008). A look in the corrosion of aluminium alloy friction stir welds. Scripta Materialia, vol. 58, no. 5, p. 383-387, DOI:10.1016/j. scriptamat.2007.10.043.

[15] Trdan, U., Grum, J. (2012). Evaluation of corrosion resistance of AA6082-T651 aluminium alloy after laser shock peening by means of cyclic polarisation and els methods. Corrosion Science, vol. 59, p. 324-333, DOI:10.1016/j.corsci.2012.03.019.

[16] Oosterkamp, A., Djapic Oosterkamp, L., Nordeide, A. (2004). Kissing bond phenomena in solid state welds of aluminum alloys. Supplement to the Welding, vol. 83, no. 8 , p. $225 \mathrm{~S}-231 \mathrm{~S}$.

[17] Elangovan, K., Balasubramanian, V. (2007). Influences of pin profile and rotational speed of the tool on the formation of friction stir processing zone in AA2219 aluminium alloy. Materials Science and Engineering: $A$, vol. 459, no. 1-2, p. 7-18, DOI:10.1016/j. msea.2006.12.124.

[18] Baldwin, K.R., Robinson, M.J., Smith, C.J.E. (1994). The Corrosion Behaviour of Electrodeposited ZincNickel Alloy Coatings on Exposure to the Marine Atmosphere, vol. 3, p. 165-175, The Chameleon Press, London. 